\title{
Determination of Atterbeg Limits Based on Wave Propagation Techniques
}

\author{
Mohammad Reza MoTAHARI \\ Dept. of Civil Engineering, Faculty of Engineering, Arak University, Arak \\ M-Motahari@araku.ac.ir
}

\begin{abstract}
Wave propagation techniques have been extensively used for many years in geotechnical engineering. Since these techniques are nondestructive and easy to apply, they have been used increasingly for determination of dynamic properties of rocks and soils. In this study, a seismic refraction survey line was conducted across two boreholes, and the Atterberg limits were calculated using laboratory test, and equation related between Atterberg limits and $V_{p}$ which identify from seismic refraction method. Experimental results showed that the Liquid limit have a good correlation while Plastic limit and Plasticity index show moderate and poor correlation, respectively. Finally, the seismic refraction method can be used for Liquid limit and Plastic limit calculation.
\end{abstract}

Keywords: Wave propagation, Atterberg limits, Liquid limit, Plastic limit, Plasticity index.

\section{1: Introduction}

Wave propagation in saturated soils has investigated (Biot 1956; Garg et al. 1974; Gajo 1996; Miura et al. 2001). Laboratory study shows that relations between rock properties and sound velocity is closely related to rock properties (D'Andrea et al. 1965; Deere and Miller 1966; Youash 1970; Gardner et al. 1974; Lama and Vutukuri 1978; Inoue and Ohomi 1981; Goktan 1988; Gaviglio 1989; Grasso et al. 1992; Kilic 1995; Chrzan 1997; Boadu 2000; Kahraman 2001). In this study, the Atterberg Limit (LL, PL and PI) were calculated using $\mathrm{V}_{\mathrm{p}}$, identify by seismic refraction method and the values were compared with the actual values identified from laboratory test. If the values match, seismic refraction measurement can be used for engineering and geotechnical investigation.

\section{2: Methodology}

\section{2-1: Seismic Refraction}

Seismic refraction method is widely utilized in delineation of the deep earth layers, determination of the physical properties of ground and in solution of the engineering problems such as selection of dumping and settling areas and designation of the bearing capacity for engineering structures (Grand and West, 1965; Sarma and Iossifelis, 1990; Budhu and Al-Karni, 1993; Richards et al., 1993; Dormieux and Pecker, 1995; Paolucci and Pecker, 1997; Soubra, 1997; Reynolds, 1997; Kumar and Rao, 2002; Kumar and Kumar, 2003; Turker, 2004; Coudhury and Subba , 2005; Othman, 2005; Tezcan et al., 2006; Ulugergerli and Uyanik, 2007). The method provides elastic properties of subsurface layers for engineering applications (Grant and West, 1965). The usage fields are easily extended to various interdisciplinary problems, as quality control of ground before and after compaction and determination of the degree of 
compaction and compaction efficiency (Uyanik and Ulugergerli, 2008). Delineation of alteration zones, investigation of cavities, establishing the occurrence, locations and apertures of structural discontinuities, determination of zones of structural weakness in the basement, and stability analysis of the ground together with the determination of mechanical properties of the rocks, may also be obtained via evaluation of seismic velocities, $V_{p}$ and Atterberg limits. $V_{p}$ were correlated with the corresponding value of Atterberg limits (Liquid limit, LL; Plastic limit, PL and Plasticity index, LI).

\section{2-2: Atterberg limits}

The Atterberg limits are index soil properties that are mainly used for identification, description, and classification of fine-grained soils. These index properties are defined as the water content necessary for a soil to flow as a plastic, semisolid or as fluid. Alternatively, liquid limit is defined as the water content at which the soil yields shear strength of approximately $2 \mathrm{kPa}$ (Seed et al. 1964a). Note that the Atterberg limits are run in remolded soils where an effect of stress history, suction, cementation, and aging of the original soil are no longer present. As a result, the Atterberg limits reflect the effect of electrical forces at the mineral surface-water interphase. For a given soil, these forces depend on the specific surface area, the cation exchange capacity, and the chemistry of the pore fluid (Mitchell and Soga 2005). With caution, the Atterberg limits can be used to estimate some engineering parameters, including permeability, coefficient of consolidation, compression index, and swelling potential (see Seed et al. 1962; Kulhawy and Mayne 1990).

\section{2-3: P-wave and Atterberg limits}

The P-wave velocity, $\mathrm{V}_{\mathrm{p}}$ in soils is a function of the different parameters (Eq 1), whereas the Atterberg limits mainly yield an indication of how much soil particles absorb water on their surface (Seed et al. 1964a, 1964b).

$$
\mathrm{V}_{\mathrm{p}}=\sqrt{\frac{\mathrm{M}}{\rho}}=\sqrt{\frac{\lambda+2 \mathrm{G}}{\rho}}
$$

where $M$ is the constrained modulus, $\lambda$ is the Lame constant, $G$ is the shear modulus, and $\rho$ is the bulk mass density.

The constrained and shear moduli in soils are dependent on several parameters, including the state of effective stresses (Duffy and Mindlin 1957; Roesler 1979), void ratio (Hardin and Black 1968), cementation (Acar and El-Tahir 1986), suction and water content (Sheeran et al. 1967; Qian et al. 1991; Cho and Santamarina 2001; Inci et al. 2003), and stiffness of the mineral, water and air phases (Santamarina et al. 2001; Fratta et al. 2005). Therefore, $\mathrm{V}_{\mathrm{p}}$ will be dependent on the Atterberg limits. In addition, published data from Yesiller et al. (2000) can also be used to indicate the poor correlation between the Atterberg limits and the $V_{p}(E q 2-4)$. All these observations challenge the use of $V_{p}$ for evaluating the Atterberg limits because the $V_{p}$ in soils depends on a complex relationship between several parameters and current state of stresses. Wave propagation monitoring is a very robust technique for the evaluation of processes and behavior of geomaterials (Fener et al. 2005). 
Bulletin de la Société royale des Sciences de Liège, Vol. 85, 2016, p. 750 - 755

\begin{tabular}{llr}
\hline $\mathrm{LL}=-32.71 \ln \mathrm{V}_{\mathrm{P}}+242.75$ & $r=0.77$ & $(2)$ \\
\hline $\mathrm{PL}=-16.23 \ln \mathrm{V}_{\mathrm{P}}+120.81$ & $r=0.75$ & $(3)$ \\
\hline $\mathrm{PI}=-16.49 \ln \mathrm{V}_{\mathrm{P}}+121.95$ & $r=0.79$ & $(4)$ \\
\hline
\end{tabular}

where $\mathrm{V}_{\mathrm{P}}$ is the $\mathrm{P}$-wave velocity $(\mathrm{m} / \mathrm{s})$, and $r$ is correlation coefficients.

\section{3: Results}

\section{3-1: Laboratory test}

The main of conducting a laboratory test are to identify types of soil and to determine their engineering properties such as strength, volume change for $\mathrm{BH} 3$ and $\mathrm{BH} 5$ soils samples. The relevant standard used is according to BS 1377-1975. The following laboratory test was carried out on selected sample at various penetrations; natural moisture content; Atterberg limits and particle size distribution of coarse and fine grained size (Table 1).

Table 1: Laboratory test values for selected samples of BH3 and BH5.

\begin{tabular}{|c|c|c|c|c|c|c|c|}
\hline \multirow[t]{2}{*}{$\mathrm{BH}$} & \multirow[t]{2}{*}{ Sample No } & \multicolumn{2}{|c|}{$\operatorname{Depth}(\mathrm{m})$} & \multirow[t]{2}{*}{ Water content $(\%)$} & \multicolumn{3}{|c|}{ Atterberg limits } \\
\hline & & From & To & & LL & PL & PI \\
\hline \multirow{5}{*}{3} & D2 & 3 & 3.45 & 19 & 40 & 27 & 13 \\
\hline & D6 & 9 & 9.45 & 34 & 46 & 30 & 16 \\
\hline & D8 & 12 & 12.45 & 29 & 41 & 28 & 13 \\
\hline & D11 & 16.5 & 16.95 & 35 & 47 & 30 & 17 \\
\hline & D16 & 24 & 24.34 & 22 & 42 & 28 & 14 \\
\hline \multirow{4}{*}{5} & D1 & 6 & 6.45 & 16 & 46 & 30 & 16 \\
\hline & D4 & 13.5 & 13.95 & 29 & 41 & 29 & 12 \\
\hline & D6 & 9 & 9.45 & 19 & 45 & 39 & 16 \\
\hline & D8 & 10.5 & 10.95 & 14 & 41 & 28 & 13 \\
\hline
\end{tabular}

\section{3-2: P-wave velocity measurement}

Seismic refraction data were collected using a standard seismograph with 24 channels, $28 \mathrm{~Hz}$ geophones and $20 \mathrm{~kg}$ weight drop of $1.5 \mathrm{~m}$ high. One seismic refraction survey line with the length of $115 \mathrm{~m}$ was conducted across the BH3 and BH5 which situated at distance $103 \mathrm{~m}$ and $112 \mathrm{~m}$ respectively along the line. Figure 1 shows velocity distribution of $\mathrm{V}_{\mathrm{p}}$ for the survey line. 


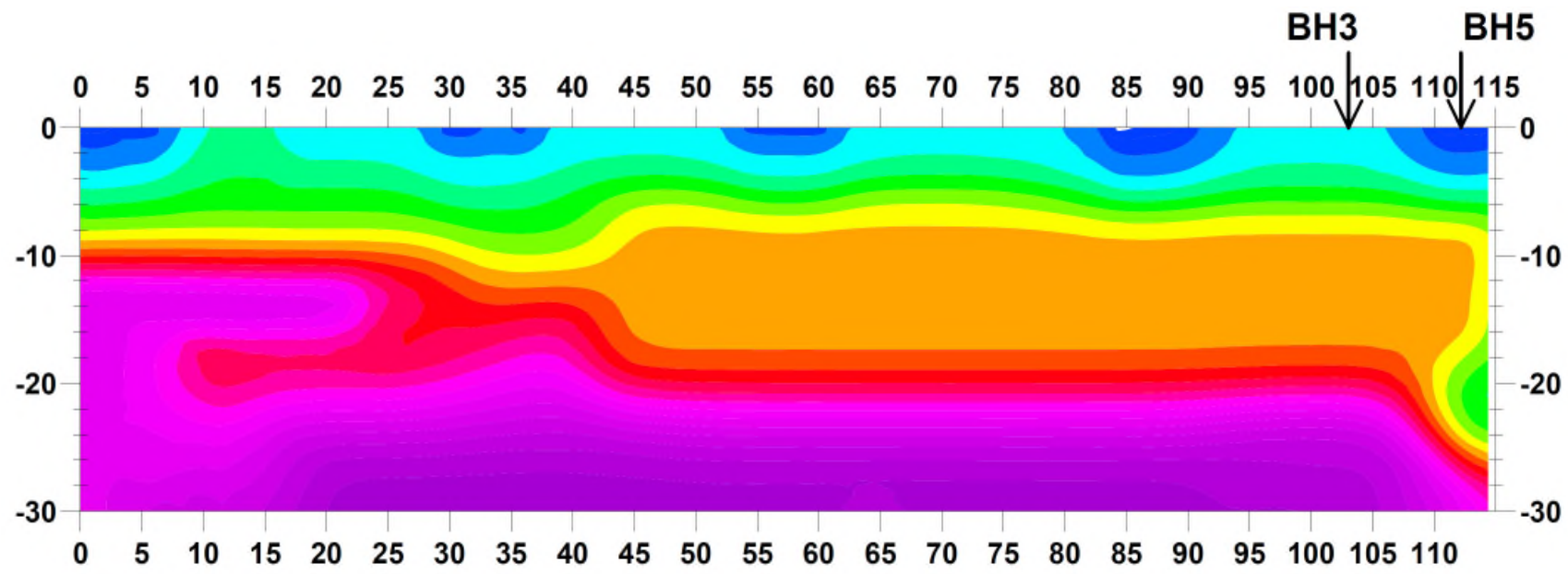

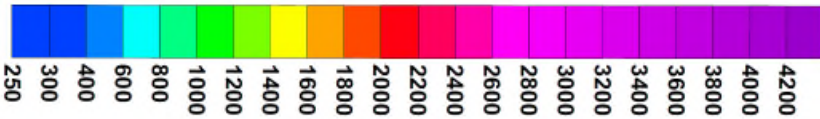

Figure 1: Seismic velocity, $V_{p}$ distribution along the survey line and boreholes position

\section{3-3: Attenberg limit calculation}

Equation 2-4 show the mathematical relationship of $\mathrm{V}_{\mathrm{p}}$ and Atterberg limits (LL, PL and LI) and Table 2 show the calculated values of Atterberg limits of $\mathrm{BH} 3$ and $\mathrm{BH} 5$ at appropriate depth using $\mathrm{V}_{\mathrm{p}}$, identified by seismic refraction method. The difference between the calculated and laboratory analysis were calculated and show in percentage towards laboratory values.

Table 2: Atterberg limit value from Laboratory test and calculated using $\mathrm{V}_{\mathrm{p}}$ identified by seismic refraction method

\begin{tabular}{|c|c|c|c|c|c|c|c|c|c|c|c|c|c|}
\hline \multirow[t]{2}{*}{$\mathrm{BH}$} & \multirow{2}{*}{$\begin{array}{l}\text { Sample } \\
\text { No }\end{array}$} & \multicolumn{2}{|c|}{$\begin{array}{c}\text { Depth } \\
(\mathrm{m})\end{array}$} & \multicolumn{3}{|c|}{$\begin{array}{c}\text { Atterberg } \\
\text { limits (Lab) }\end{array}$} & \multicolumn{3}{|c|}{$\begin{array}{c}\text { Atterberg limits } \\
\text { (Calculated) }\end{array}$} & \multirow{2}{*}{$\begin{array}{c}\begin{array}{c}\mathrm{V}_{\mathrm{p}} \\
(\mathrm{m} / \mathrm{S})\end{array} \\
-\end{array}$} & \multicolumn{3}{|c|}{$\begin{array}{c}\text { Difference } \\
(\%)\end{array}$} \\
\hline & & From & To & $\mathrm{LL}$ & $\mathrm{PL}$ & PI & $\mathrm{LL}$ & PL & PI & & LL & $\mathrm{PL}$ & PI \\
\hline \multirow{3}{*}{3} & D6 & 9 & 9.45 & 46 & 30 & 16 & 46 & 23.187 & 22.763 & 409.52 & 0 & 22.7 & 42.2 \\
\hline & D8 & 12 & 12.45 & 41 & 28 & 13 & 41 & 20.242 & 20.242 & 477.15 & 0 & 26.1 & 55.7 \\
\hline & D11 & 16.5 & 16.95 & 47 & 30 & 17 & 47 & 23.683 & 23.267 & 397.19 & 0 & 21.1 & 36.8 \\
\hline 5 & D4 & 13.5 & 13.95 & 41 & 29 & 12 & 41 & 20.705 & 20.242 & 477.15 & 0 & 28.6 & 68.6 \\
\hline
\end{tabular}

\section{4: Discussion}

The Liquid limit, LL shows good correlation with $0 \%$ different, while Plastic limit, PL show moderate correlation with less than $28 \%$ different and Plasticity index, PI shows poor correlation with less than $68.6 \%$ different. Generally the seismic refraction method can be used for Liquid limit and Plastic limit calculation. 
Bulletin de la Société royale des Sciences de Liège, Vol. 85, 2016, p. 750 - 755

\section{References}

[1] ASTM. 1990. Soil and rock; dimension stone; Geosynthetics. American Society for Testingand Materials (ASTM), Sect. 4, Vol. 04.08.

[2] Biot, M.A. 1956. Theory of propagation of elastic waves in a fully saturated porous solid. I. Low frequency range. Journal of the Acoustical Society of America, 28: 168-178.

[3] Boadu, F.K. 2000. Predicting the transport properties of fractured rocks from seismic information: numerical experiments. Journal of Applied Geophysics, 44: 103-113.

[4] Chrzan, T. 1997. The determination of rocks' mechanical properties with the use of ultrasounds. In Mine Planning and Equipment Selection 1997: Proceedings of the $6^{\text {th }}$ International Symposium, Ostrava, Czech Republic, 3-9 September 1997. Edited by V. Strakos, V. Kebo, R. Farana, and L. Smutny. A.A. Balkema, Rotterdam, The Netherlands. pp. 315-318.

[5] D’Andrea, D.V., Fischer, R.L., and Fogelson, D.E. 1965. Prediction of compressive strength from other rock properties. US Bureau of Mines, Report of Investigations 6702.

[6] Deere, D.U., and Miller, R.P. 1966. Engineering classification and index properties for intact rock. US Air Force Weapons Laboratory, Kirtland Base, N.M., Technical Report AFWLTR- 65-116.

[7] Fener, M., Kahraman, S., Bay, Y., and Gunaydin, O. 2005. Correlations between P-wave velocity and Atterberg limits of cohesive soils. Canadian Geotechnical Journal, 42: 673677.

[8] Gajo, A. 1996. The effects of inertial coupling in the interpretation of dynamic soil tests. Géotechnique, 46: 245-257.

[9] Gardner, G.H.F., Gardner, L.W., and Gregory, A.R. 1974. Formation velocity and density: the diagnostic basis for stratigraphic. Geophysics, 39: 770-780.

[10] Garg, S.K., Nayfeh, A.H., and Good, A.J. 1974. Compressional waves in fluid-saturated elastic porous media. Journal of Applied Physics, 45: 1968-1974.

[11] Gaviglio, P. 1989. Longitudinal waves propagation in a limestone: the relationship between velocity and density. Rock Mechanics and Rock Engineering, 22: 299-306.

[12] Goktan, R.M. 1988. Theoretical and practical analysis of rock rippability. Ph.D. thesis, Istanbul Technical University, Istanbul, Turkey. (In Turkish.)

[13] Grasso, P., Xu, S., and Mahtab, A. 1992. Problems and promises of index testing of rocks. In Proceedings of the 33rd US Symposium on Rock Mechanics, Sante Fe, N.M., 3-5 June 1992. Edited by J.R. Tillerson and W.R. Wawersik. A.A. Balkema, Rotterdam, The Netherlands. pp. 879-888.

[14] Inoue, M., and Ohomi, M. 1981. Relation between uniaxial compressive strength and elastic wave velocity of soft rock. In Weak Rock: Proceedings of the International Symposium on Weak Rock, Tokyo, Japan, 21-24 September 1981. Edited by K. Akai, M. Hayashi, and Y. Nishimatsu. A.A. Balkema, Rotterdam, The Netherlands. pp. 9-13.

[15] Kahraman, S. 2001. Evaluation of simple methods for assessing the uniaxial compressive strength of rock. International Journal of Rock Mechanics and Mining Sciences, 38: 981994. 
[16] Kilic, R. 1995. Geomechanical properties of the ophiolites (Cankiri/Turkey) and alteration degree of diabase. Bulletin of the International Association of Engineering Geology, 51: 64-69.

[17] Lama, R.D., and Vutukuri, V.S. 1978. Handbook on mechanical properties of rocks. 2nd ed. Trans Tech Publications, Clausthal, Germany.

[18] Miura, K., Yoshida, N., and Kim, Y.-S. 2001. Frequency dependent property of waves in saturated soil. Soils and Foundations, 41: 1-19.

[19] Youash, Y. 1970. Dynamic physical properties of rocks: Part 2, Experimental result. In Proceedings of the 2nd Congress of the International Society for Rock Mechanics, Beograd, Yugoslavia, 21-26 September 1970. Institute for Development of Water Resources, Beograd, Yugoslavia. pp. 185-195. 